\title{
Spatial ecology of critically endangered hawksbill turtles Eretmochelys imbricata: implications for management and conservation
}

\author{
Alexander R. Gaos ${ }^{1,2,3, *}$, Rebecca L. Lewison ${ }^{2}$, Bryan P. Wallace ${ }^{1,4,5}$, Ingrid L. Yañez ${ }^{1}$, \\ Michael J. Liles ${ }^{1,6}$, Wallace J. Nichols ${ }^{1,7}$, Andres Baquero ${ }^{1,8,9}$, Carlos R. Hasbún ${ }^{10}$, \\ Mauricio Vasquez ${ }^{1,11}$, José Urteaga ${ }^{1,12}$, Jeffrey A. Seminoff ${ }^{1,13}$ \\ ${ }^{1}$ Eastern Pacific Hawksbill Initiative, San Diego, California 92102, USA \\ ${ }^{2}$ San Diego State University, San Diego, California 92182, USA \\ ${ }^{3}$ University of California Davis, Davis, California 95616, USA \\ ${ }^{4}$ Conservation International, Global Marine Division, Arlington 22202, Virginia, USA \\ ${ }^{5}$ Duke University Marine Lab, Division of Marine Science and Conservation, Beaufort, North Carolina 28516, USA \\ ${ }^{6}$ Texas A\&M University, College Station, Texas 77843, USA \\ ${ }^{7}$ California Academy of Sciences, San Francisco, California 94118, USA \\ ${ }^{8}$ Fundación Equilibrio Azul, PO Box 17116025, Quito, Ecuador \\ ${ }^{9}$ Universidad San Francisco de Quito, Quito 02-2971700, Ecuador \\ ${ }^{10}$ United States Agency for International Development, San Salvador 2235-2506, El Salvador \\ ${ }^{11}$ Instituto de Ciencias del Mary Limnología de la Universidad de El Salvador, San Salvador, El Salvador \\ ${ }^{12}$ Fauna and Flora International, CP 527, Managua, Nicaragua \\ ${ }^{13}$ National Oceanic and Atmospheric Administration, Southwest Fisheries Science Center, La Jolla, California 92037, USA
}

\begin{abstract}
Elucidating spatio-temporal movements of animals is an integral component of wildlife conservation and protected species management. Between 2008 and 2010 we satellite tracked 15 adult female hawksbill turtles Eretmochelys imbricata in the eastern Pacific Ocean to evaluate their movement behavior and to guide management and conservation efforts of this highly endangered population. Movements and habitat use were highly neritic, and post-nesting migration distances $($ maximum $=283.11 \mathrm{~km}$ ) were short relative to migrations of other sea turtle species. In foraging areas, the majority of hawksbills established restricted, inshore home ranges within mangrove estuaries. A large proportion (>65\%) of turtle location points fell within protected areas, although many of these sites lack enforcement and monitoring. The consistent use of estuarine and mangrove habitat for nesting and foraging may explain why hawksbills went virtually undetected in the eastern Pacific for decades. The spatially restricted and neritic life cycles of adult hawksbills in the eastern Pacific highlight threats (e.g. overlap with coastal fisheries, increased susceptibility to habitat degradation and/or catastrophic events) and opportunities for conservation (e.g. acute conservation target areas, less variant jurisdictional boundaries/regulations) for this species. Our results underscore the importance of strengthening protected area management, mangrove estuary protection and hawksbill research and conservation in the eastern Pacific.
\end{abstract}

KEY WORDS: Satellite telemetry $\cdot$ Movement $\cdot$ Home range $\cdot$ Mangrove estuary $\cdot$ Migration · Protected area $\cdot$ Eastern Pacific

\section{INTRODUCTION}

The hawksbill turtle Eretmochelys imbricata is among the most imperiled of the world's 7 marine turtle species (Wallace et al. 2011). Populations have been reduced by $>80 \%$ around the globe: within the eastern Pacific, only 200 to 300 individual hawksbills are thought to nest annually along the region's coastline (Gaos et al. 2010). These totals are fewer than the number of females that currently 
nest on several individual islands in the Caribbean (e.g. Meylan 1999, Beggs et al. 2007), highlighting the precarious state of this species in the eastern Pacific. These low observed numbers also suggest that hawksbills are unlikely to survive in the region without coordinated actions to monitor, conserve and recover the population.

Protecting both foraging and nesting grounds of older, reproductively mature individuals is particularly important to marine turtle recovery efforts due to the high conservation value of this life stage (Crouse et al. 1987, Crowder et al. 1994, Heppell et al. 1996, Heppell 1998). However, conservation efforts are complicated by the vagile nature of adult hawksbills, whose migration corridors and high-use areas are difficult to identify and often span multinational jurisdictional boundaries (Plotkin 2003, Mortimer et al. 2007). To establish effective management strategies and mitigate direct threats, it is necessary to quantify and characterize hawksbill movement, specifically migration pathways and high-use areas (Blumenthal et al. 2006, Godley et al. 2008, Shillinger et al. 2008).

Satellite telemetry has emerged as a key research method to study the movements of marine turtles (Block 2005, Godley et al. 2008), providing data on individual movements in near 'real time' (Blumenthal et al. 2006) and facilitating rapid identification of critical habitat (e.g. Horrocks et al. 2001, Troëng et al. 2005). Marine turtle movements and habitat-use patterns derived from satellite telemetry have been used to support protected area design and habitat management, and identify susceptibility to threats such as fisheries bycatch and targeted capture (Seminoff et al. 2008, Knight et al. 2009, Maxwell et al. 2011, Witt et al. 2011). Satellite telemetry has also been used to identify resource requirements, social interactions and the impact of predation, all of which are key components of marine turtle ecology and management (Schofield et al. 2007, Godley et al. 2008, Royer \& Lutcavage 2008, Shillinger et al. 2008, Gaos et al. 2012).

We recently reported the results from 12 satellitetracked hawksbill turtles in the eastern Pacific that associated with mangrove estuaries (Gaos et al. 2012). Here we extend the analysis of these tracking data to examine (1) the inter-nesting movements and (2) migration routes of these turtles, as well as to (3) conduct further analysis of the tracking data on the foraging grounds, with the specific objective of informing management and conservation strategies. We also include tracking data from 3 additional turtles.

\section{MATERIALS AND METHODS}

\author{
Study areas
}

From June 2008 to July 2010 we fitted 15 adult female hawksbill turtles Eretmochelys imbricata $($ mean \pm SD curved carapace length $=84.0 \pm 7.6 \mathrm{~cm}$ ) with satellite tags (PTTs: platform transmitter terminals) at 6 sites among 3 countries in the eastern Pacific (Table 1). This included 5 post-nesting hawksbills and 1 in-water adult female in El Salvador: 3 at Bahía Jiquilisco-Xiriualtique Biosphere Reserve (Bahia Jiquilisco) $\left(13^{\circ} 11^{\prime} \mathrm{N}, 88^{\circ} 21^{\prime} \mathrm{W}\right), 2$ at Los Cóbanos Reef Marine Protected Area (Los Cobanos) $\left(13^{\circ} 31^{\prime} \mathrm{N}, 89^{\circ} 48^{\prime} \mathrm{W}\right)$ and 1 at Punta Amapala $\left(13^{\circ} 09^{\prime} \mathrm{N}, 87^{\circ} 55^{\prime} \mathrm{W}\right)$. In Nicaragua, 2 post-nesting females were tagged at La Flor Wildlife Refuge (La Flor) $\left(11^{\circ} 08^{\prime} \mathrm{N}, 85^{\circ} 47^{\prime} \mathrm{W}\right)$ and 2 at Estero Padre Ramos Natural Reserve (Estero Padre Ramos) $\left(12^{\circ} 47^{\prime} \mathrm{N}, 87^{\circ} 29^{\prime} \mathrm{W}\right)$. In Ecuador, satellite tags were applied to 4 post-nesting hawksbills and 1 in-water adult female (which emerged to nest shortly after tagging) at Machalilla National Park (Machalilla) $\left(01^{\circ} 33^{\prime} \mathrm{S}, 80^{\circ} 50^{\prime} \mathrm{W}\right)$.

\section{Tags and data processing}

We used a variety of PTT models manufactured by Wildlife Computers (SPLASH, SDR-T16, Spot 5, MK10) and Telonics (ST-20, SDR-T16) varying in size, weight and design. In all cases, transmitters were attached to the highest point of each turtle's carapace using a 2-part epoxy (Mitchell 1998).

Turtle position data were acquired through the Argos system (Landover, Maryland) using a newly developed Kalman geoprocessing algorithm (Lopez \& Malardé 2011) to categorize locations into 1 of 6 location classes (LCs). The Kalman LC (3, 2, 1, 0, A and $\mathrm{B}$ ) precision estimates are the same as those used for the traditional Argos least-squares geoprocessing algorithm (see Argos 2008 for details on precision and error estimates), with the major improvement of Kalman being the ability to compute locations from 1-message transmissions (also categorized as LCB) and increased overall accuracy of all LCs (Lopez \& Malardé 2011).

Hays et al. (2001) suggested omitting LCB locations from movement analyses due to large base variance and the occurrence of outliers (Royer \& Lutcavage 2008). However, as has been the case with other hawksbill telemetry studies (e.g. Troëng et al. 2005, Cuevas et al. 2008), the overwhelming majority of 
Table 1. Eretmochelys imbricata. Data for the 15 hawksbills tracked in the present study, including turtle ID number, curved carapace length (CCL), release date, release site/country, deployment duration and displacement. -: turtles were not tracked during the migration phase

\begin{tabular}{|c|c|c|c|c|c|}
\hline Turtle ID & $\begin{array}{l}\text { CCL } \\
(\mathrm{cm})\end{array}$ & $\begin{array}{l}\text { Release date } \\
\text { (dd.mm.yy) }\end{array}$ & Release site/country & $\begin{array}{l}\text { Deployment } \\
\text { duration (d) }\end{array}$ & $\begin{array}{c}\text { Displacement } \\
(\mathrm{km})\end{array}$ \\
\hline 17434 & 74 & 16.07 .09 & Los Cobanos, El Salvador & 148.7 & 18.07 \\
\hline 42987 & 87 & 13.07 .09 & Los Cobanos, El Salvador & 82.3 & 136.61 \\
\hline 5155 & 83 & 10.07 .08 & Bahia Jiquilisco, El Salvador & 424.8 & 35.30 \\
\hline 79784 & 89 & 10.07 .08 & Bahia Jiquilisco, El Salvador & 178.0 & - \\
\hline 5394 & 74 & 11.07 .08 & Bahia Jiquilisco, El Salvador & 207.8 & 59.73 \\
\hline 42993 & 83 & 15.07 .09 & Punta Amapala, El Salvador & 184.5 & 37.62 \\
\hline 5396 & 83 & 01.07 .09 & La Flor, Nicaragua & 198.8 & 283.11 \\
\hline 37616 & 68 & 01.07 .09 & La Flor, Nicaragua & 30.7 & - \\
\hline 78501 & 79 & 09.07 .10 & Estero Padre Ramos, Nicaragua & 21.5 & 107.11 \\
\hline 80590 & 88 & 09.07 .10 & Estero Padre Ramos, Nicaragua & 70.6 & 63.82 \\
\hline 37623 & 92 & 11.01 .09 & Machalilla, Ecuador & 68.9 & 215.42 \\
\hline 52670 & 88 & 13.01 .09 & Machalilla, Ecuador & 78.9 & 194.83 \\
\hline 44359 & 93 & 01.02 .09 & Machalilla, Ecuador & 104.8 & 90.46 \\
\hline 22130 & 95 & 21.11 .09 & Machalilla, Ecuador & 64.4 & - \\
\hline 37613 & 85 & 17.01 .10 & Machalilla, Ecuador & 30.3 & - \\
\hline
\end{tabular}

our LCs were categorized as B $(87.0 \%$; Table 2). Leaving out these points would have represented the loss of valuable location data, many of which can be as accurate as LCAs (Argos 2008), and this, in turn, would have forced the abandonment of particular analyses (e.g. home range estimation) important for understanding movement patterns. The implementation of a series of filters to exclude biologically unreasonable results of location points, including travel speed $\left(>5 \mathrm{~km} \mathrm{~h}^{-1}\right)$ and internal turning angles $\left(<12.5^{\circ}\right)$ (Luschi et al. 1998, Hays et al. 1999), allowed us to confidently include many LCB points in our analyses. Due to the nearshore and inshore waterways occupied by tracked turtles, we also implemented an elevation $(>30 \mathrm{~m})$ and an inshore filter, the latter of which took the maximum on-land distance of the generally more precise LCs 1, 2, 3 and A (Royer \& Lutcavage 2008) as a reference to eliminate on-land LCBs. The use of the Kalman geoprocessing algorithm, which increased the number of LCBs by

Table 2. Eretmochelys imbricata. Total location points by location class (LC3 to LCB) for 15 hawksbills tracked in the present study

\begin{tabular}{|lrc|}
\hline Location class & Points & Percentage \\
\hline LC3 & 127 & 1.4 \\
LC2 & 91 & 1.0 \\
LC1 & 70 & 0.8 \\
LC0 & 11 & 0.1 \\
LCA & 857 & 9.7 \\
LCB & 7723 & 87.0 \\
\hline
\end{tabular}

$>2$-fold when compared to the traditional least squares algorithm, enabled us to perform analyses that would not have been possible using the latter.

Tracks of turtles were plotted and analyzed using the satellite tracking and analysis tool (STAT; Coyne \& Godley 2005), as well as ArcGIS V.9.3.1 (Environmental Systems Research Institute) and the associated extension, Hawth's analysis tools (Beyer 2004). We temporally separated location points by $\geq 4 \mathrm{~h}$ (Swihart \& Slade 1985, Schmid et al. 2002, Seminoff et al. 2002) to minimize spatial autocorrelation, while locations transmitted $<24 \mathrm{~h}$ post-release were eliminated to compensate for potentially unusual behavior resulting from stress or reactions induced during turtle capture and retention.

\section{Movement phases and in-phase calculations}

Displacement plot curves, which plot distance traveled over time tracked, were used to identify transitions between different movement phases (Godley et al. 2003). These phase transitions are identified based on inflection points that correspond to changes in travel speed as turtles commence and/or complete migratory movements (Seminoff et al. 2008). Displacement curves were used to partition the tracks for each turtle (or identify use of a single movement phase) and establish 3 distinct movement phases: (1) inter-nesting, (2) migration and (3) foraging (sensu Godley et al. 2003, Blumenthal et al. 2006, Seminoff et al. 2008). 
To evaluate whether post-nesting migratory movements were direct or tortuous, we calculated a migration straightness index (MSI) for each turtle based on the ratio of straight line distance between first and last location points to the total track length of the migration phase (Luschi et al. 1998, Nichols et al. 2000, Godley et al. 2002, Seminoff et al. 2008). Postnesting movements not exceeding the distances travelled during the inter-nesting phase for individual turtles were categorized as non-migratory behavior (Godley et al. 2008).

\section{Home range areas}

Home range areas were calculated for turtles during the inter-nesting and foraging phases using a convexhull nonparametric method called local nearestneighbor convex hull (LoCoH; Getz \& Wilmers 2004). This method takes the union of the local polygon hulls associated with each location point and its nearest neighbors (Getz \& Wilmers 2004) and constructs isopleths by merging these local polygons, starting with the smallest and ending with the largest (Getz \& Wilmers 2004, Getz et al. 2007). These merged polygons are defined as the utilization distributions (UDs). Unlike traditional kernel home range methods, one of the major advantages of $\mathrm{LoCoH}$ is that it converges on the true distribution of area used with the successive addition of data (Getz \& Wilmers 2004, Loveridge et al. 2009). $\mathrm{LoCoH}$ home range areas depend on a heuristic $k$-value (Getz et al. 2007), which we selected using the minimum spurious hole method (Getz \& Wilmers 2004) and by running $k$-values from 5 to 40 to identify an asymptote corresponding to stable areas across a range of $k$-values for the $50 \%$ isopleths (Loveridge et al. 2009). Inter-nesting and foraging home ranges were classified as either 'inshore' if turtles settled within estuaries or 'nearshore' if turtles settled in areas along the open coast. No home ranges were calculated for turtles with $<20$ location points during the inter-nesting or foraging phases.

The LoCoH method is well suited for cases where animals are restricted by known boundaries or impassable barriers, as topological features can be incorporated into the analysis (Getz \& Wilmers 2004). Despite the use of $\mathrm{LoCoH}$, sets of fixes were often located on or immediately adjacent to non-suitable habitat (i.e. land), resulting in UDs that extended over these areas. We subtracted areas of landmass for all reported home range values (Creel \& Creel 2002, Urian et al. 2009) and used 90 and $50 \%$ UDs to represent the overall home range and core area of activity, respectively (Powell 2000). As an additional measure of habitat use, we also calculated the amount of coastline $(\mathrm{km})$ occupied by turtles during the different phases by taking the maximum measurement of the 2 farthest separated location points whose intersecting line was parallel to the coast.

\section{Coastal features}

We analyzed the location of turtles with respect to land features and marine protected areas (MPA). MPA boundaries were downloaded from the World Database on Protected Areas (www.wdpa.org). Land features were manually digitized from remotely sensed, high-resolution images available through Environmental Systems Research Institute's online Resource Center (http://resources.arcgis.com).

\section{Statistical analyses}

To evaluate potential relationships among variables (e.g. turtle size, range area) we used Spearman rank correlations. Mean values, ranges and standard deviations (SD) are reported throughout the present paper. Statistical analyses were carried out in Systat V.12 (SYSTAT Software).

\section{RESULTS}

Over the duration of the tracking period we received a combined total of 8879 location points from the 15 PTTs (see Table 2). After implementing our data filtering methods, $3166(35.7 \%)$ location points were available for analysis. The number of location points available for the inter-nesting, migration and foraging movement phases differed depending on satellite positions, tag emergence, climatic conditions and time spent by individual turtles in each phase. Three turtles were only tracked during the internesting phase, 1 turtle was only tracked during the foraging phase and 11 turtles were tracked during all 3 movement phases (see Tables $\mathrm{S} 1$ to $\mathrm{S} 3$ in the supplement at www.int-res.com/articles/suppl/m450 p181_supp.pdf).

\section{Inter-nesting phase}

We analyzed a total of 720 location points (371 total tracking days) from 14 turtles for the inter-nesting 
phase (see Table S1 in the supplement), during which turtles were tracked on average for $24.7 \pm$ $17.2 \mathrm{~d}$. The average distance of turtles (in-water) from their original site of oviposition during the internesting phase was $7.03 \mathrm{~km}$, but the distance varied among individual turtles $(\mathrm{SD}=5.24)$. The mean distance of turtles from the coast was $0.99 \pm 0.69 \mathrm{~km}$, while the average length of coastline used was $15.94 \pm 13.61 \mathrm{~km}$ and the average distance travelled per day was $3.87 \pm 1.84 \mathrm{~km}$.

Turtles used either inshore $(28.6 \%)$ (Fig. 1) or nearshore (71.4\%) (Fig. 2) inter-nesting home range areas. The mean $90 \%$ UD area for the 12 turtles for which inter-nesting home ranges were calculated was $31.23 \pm 33.05 \mathrm{~km}^{2}$, and the mean $50 \%$ UD area was $5.07 \pm 5.50 \mathrm{~km}^{2}$. Both the 90 and $50 \%$ internesting home range areas for inshore turtles were substantially smaller, with a mean $90 \%$ UD of $13.46 \pm$ $9.64 \mathrm{~km}^{2}$ and a mean $50 \%$ UD of $2.03 \pm 0.97 \mathrm{~km}^{2}$ (Table 3). There were no correlations between turtle size or tracking duration and the area of inter-nesting home range areas.

\section{Migration phase}

We analyzed a total of 264 location points (89 total tracking days) from 11 turtles for the migration phase (see Table S2 in the supplement). Post-nesting turtles migrated to foraging grounds in El Salvador, Hon- duras and Ecuador (Fig. 3). The shortest turtle migrations $(\mathrm{n}=3$, range $=18.07$ to $37.62 \mathrm{~km})$ were classified as Type A3 ('local residence') following Godley et al. (2008), while all other $(n=8)$ were classified as Type A1 ('coastal movements to neritic foraging grounds'; Godley et al. 2008). The average migration distance for all turtles was $112.92 \pm 85.56 \mathrm{~km}$, and the distance travelled varied among individuals, but no turtle surpassed $283.11 \mathrm{~km}$ (Table 1). The mean migration duration for turtles was $8.2 \pm 4.9 \mathrm{~d}$, and the average distance travelled per day was $15.96 \pm$ $7.12 \mathrm{~km}$.

Turtles never ventured $>4.20 \mathrm{~km}$ from shore (mean $\pm \mathrm{SD}=1.72 \pm 1.33 \mathrm{~km}$, and this association with the coast reduced their MSI values as they were forced to circumnavigate terrestrial features (e.g. coastal headlands) during migrations. Even following the coastline features, turtles took relatively direct routes to their foraging areas (mean MSI $=0.70 \pm 0.20$ ) with an average speed of $0.95 \pm 0.36 \mathrm{~km} \mathrm{~h}^{-1}$. The one exception was Turtle 42993, which took a much more tortuous route $\left(\mathrm{MSI}=0.30\right.$, speed $\left.=0.36 \mathrm{~km} \mathrm{~h}^{-1}\right)$, displacing $37.62 \mathrm{~km}$ over a period of $16.6 \mathrm{~d}$.

\section{Foraging phase}

We analyzed a total of 2191 location points (1432 total tracking days) from 12 turtles for the foraging phase (see Table S3 in the supplement), during

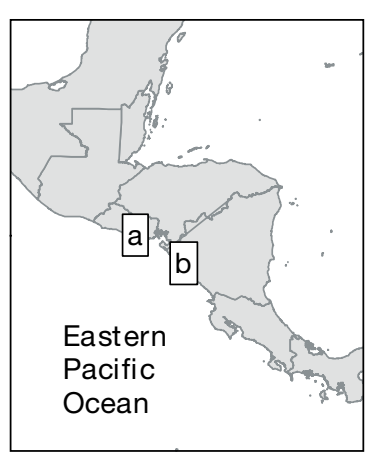

\section{Bahia Jiquilisco, El Salvador}

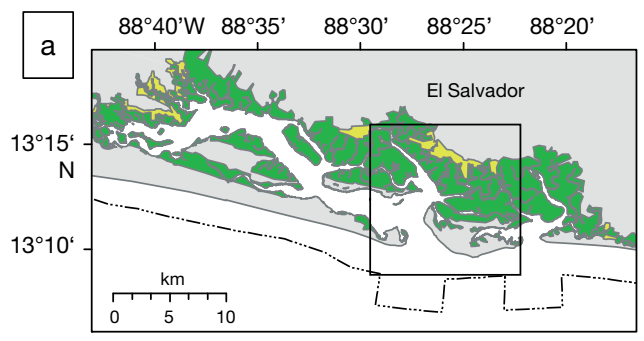

Estero Padre Ramos, Nicaragua
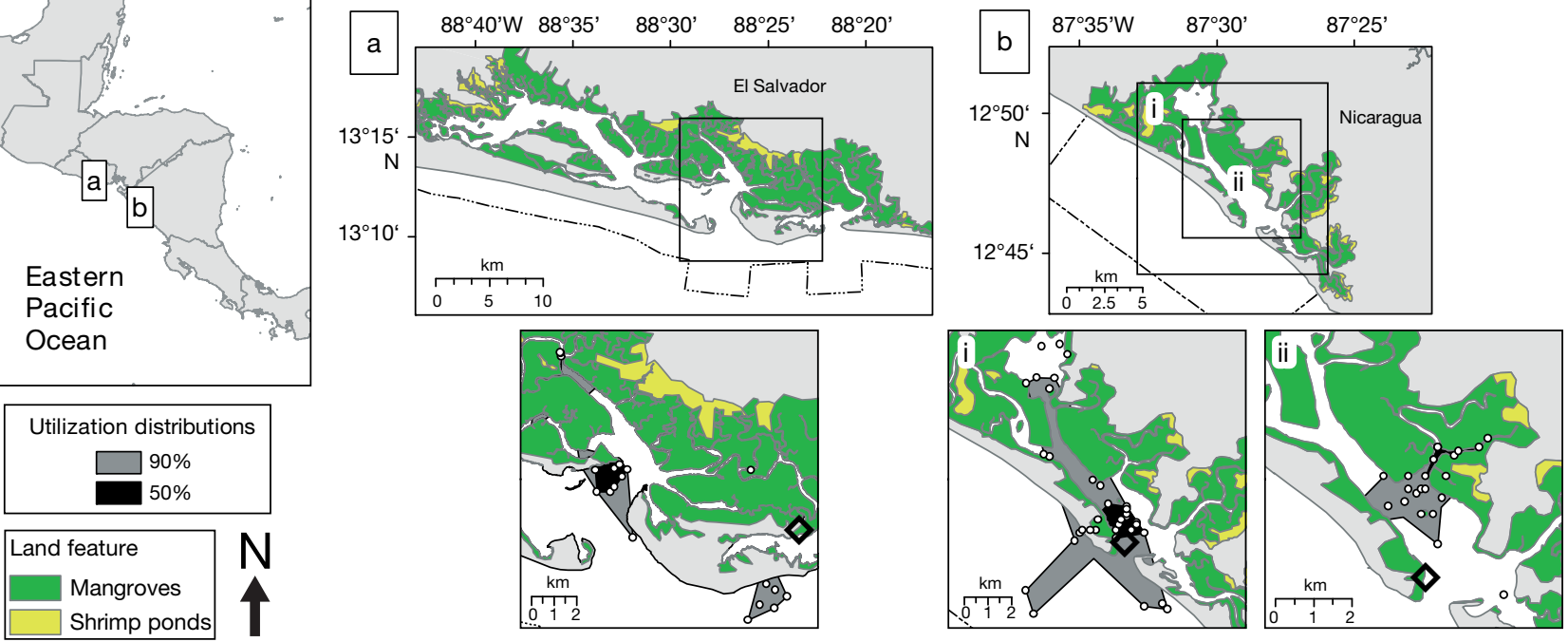

Fig. 1. Eretmochelys imbricata. Inshore (i.e. within estuaries) inter-nesting home ranges for turtles at (a) Bahia Jiquilisco, El Salvador ( $\mathrm{n}=1$ ) and (b) Estero Padre Ramos, Nicaragua ( $=2$; i to ii), with $90 \%$ (dark grey) and $50 \%$ (black) utilization distributions (UDs). Only location points and UDs over water are shown here. Mangrove saltwater forests (green), shrimp ponds (i.e. converted mangrove saltwater forests) (yellow), release sites (diamonds) and marine protected areas (dashed lines) shown for reference 
Los Cobanos, El Salvador
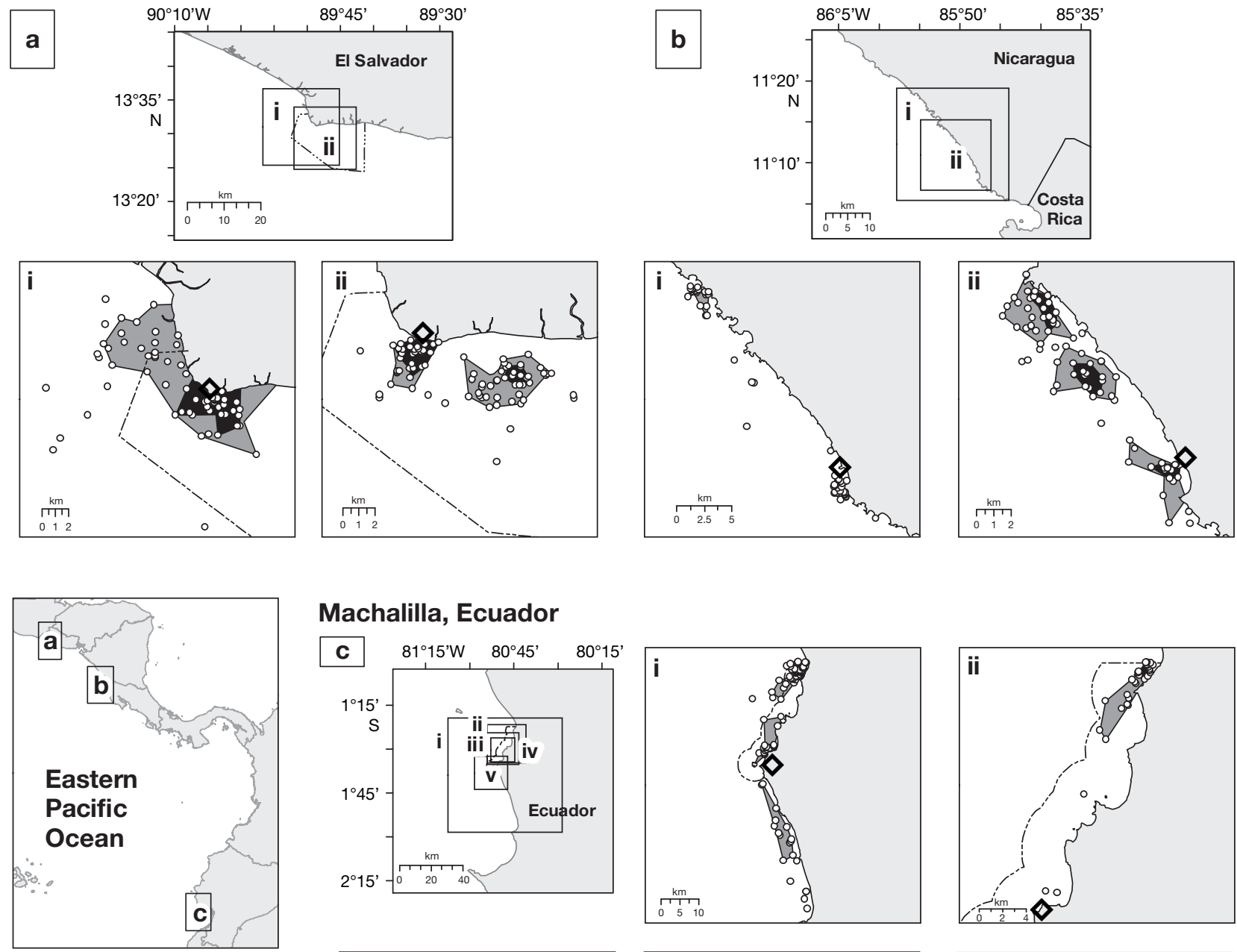

Machalilla, Ecuador
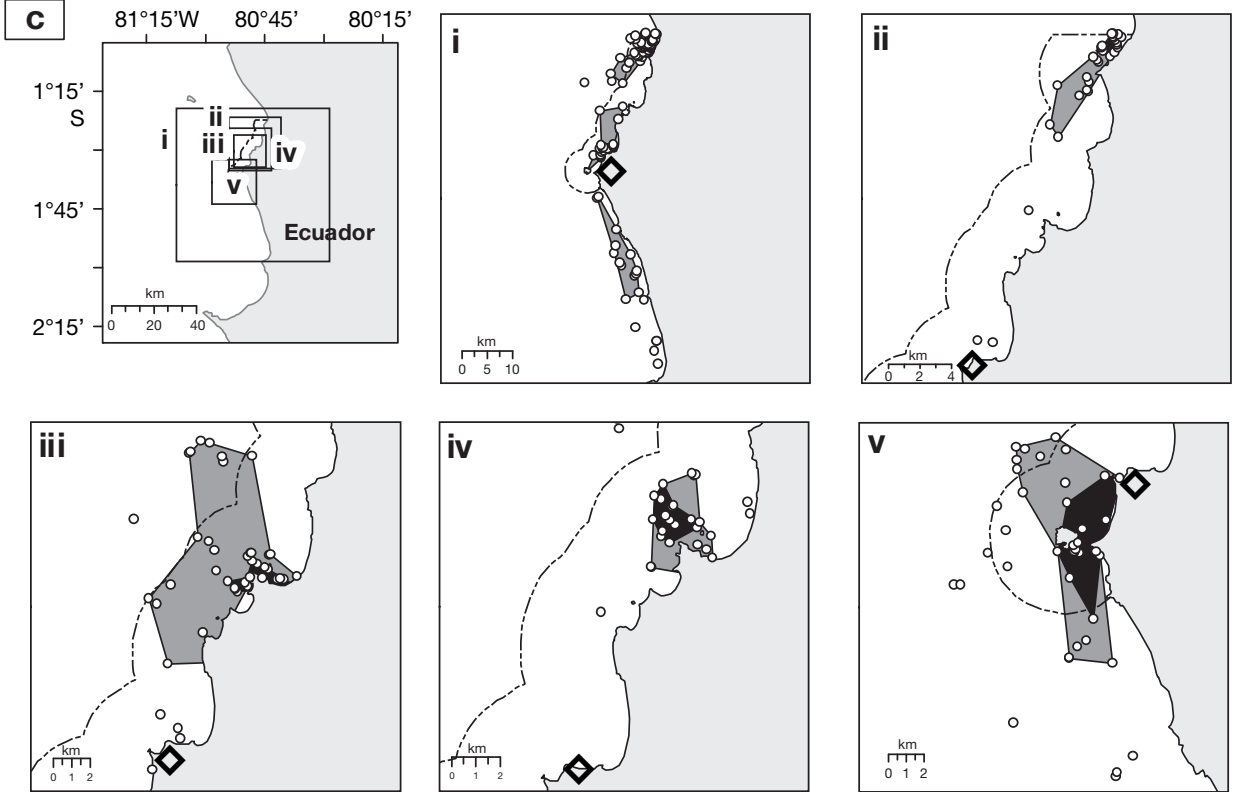

Fig. 2. Eretmochelys imbricata. Nearshore (i.e. open-coast) inter-nesting home ranges for turtles at (a) Los Cobanos, El Salvador ( $\mathrm{n}=2$; i \& ii), (b) La Flor, Nicaragua ( $=2$; i \& ii) and (c) Machalilla, Ecuador ( $\mathrm{n}=5$; i to v), with $90 \%$ (dark grey) and $50 \%$ (black) utilization distributions (UDs). Only location points and UDs over water are shown here. Release sites (diamonds) and marine protected areas (dashed lines) shown for reference

which turtles were tracked on average for $95.5 \pm$ $110.3 \mathrm{~d}$. Their mean distance from the coast was $0.31 \pm 0.47 \mathrm{~km}$ (range $=0.01$ to 1.29 ), while for turtles that established inshore foraging home ranges (see below) the mean distance was $0.12 \pm 0.24 \mathrm{~km}$. The average length of coastline used was $9.36 \pm 4.01 \mathrm{~km}$, and the average distance travelled per day was $2.54 \pm 1.68 \mathrm{~km}$.

Turtles established either inshore (83.3\%) (Fig. 4) or nearshore (16.7\%) (Fig. 5) foraging home ranges. The mean $90 \%$ UD area for the 11 turtles for which foraging home ranges were calculated was $6.95 \pm$ 


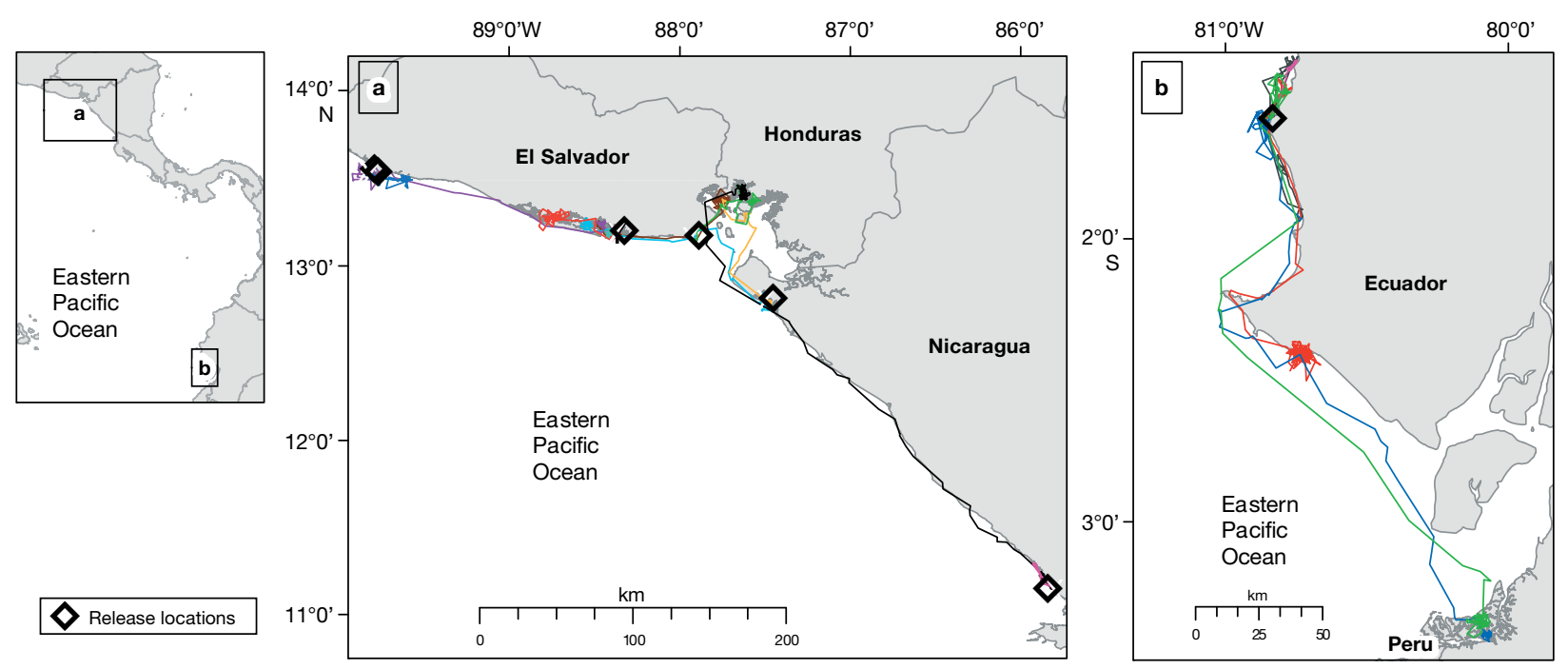

Fig. 3. Eretmochelys imbricata. Tracks of 15 hawksbills equipped with satellite tags in (a) central America and (b) Ecuador in the present study between 2008 and 2010. Release sites (diamonds) shown for reference

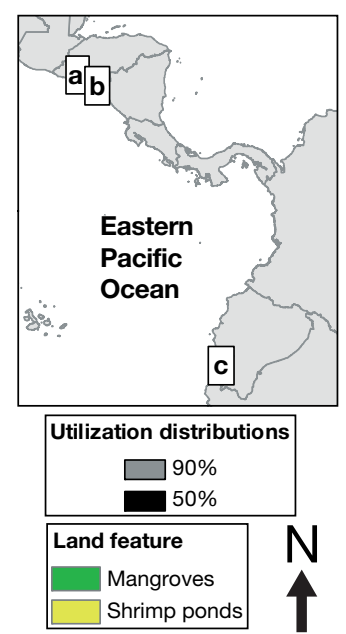

Gulf of Fonseca, Honduras

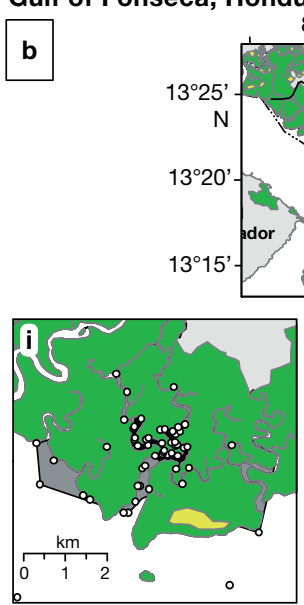

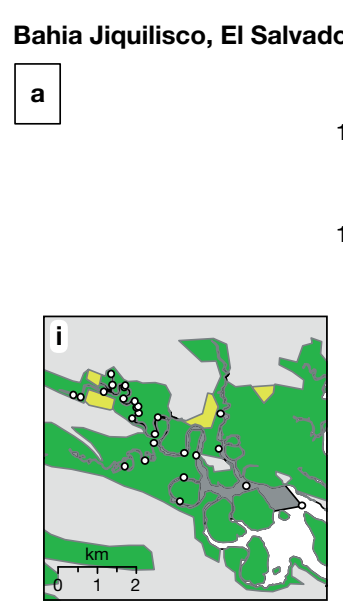

(1)
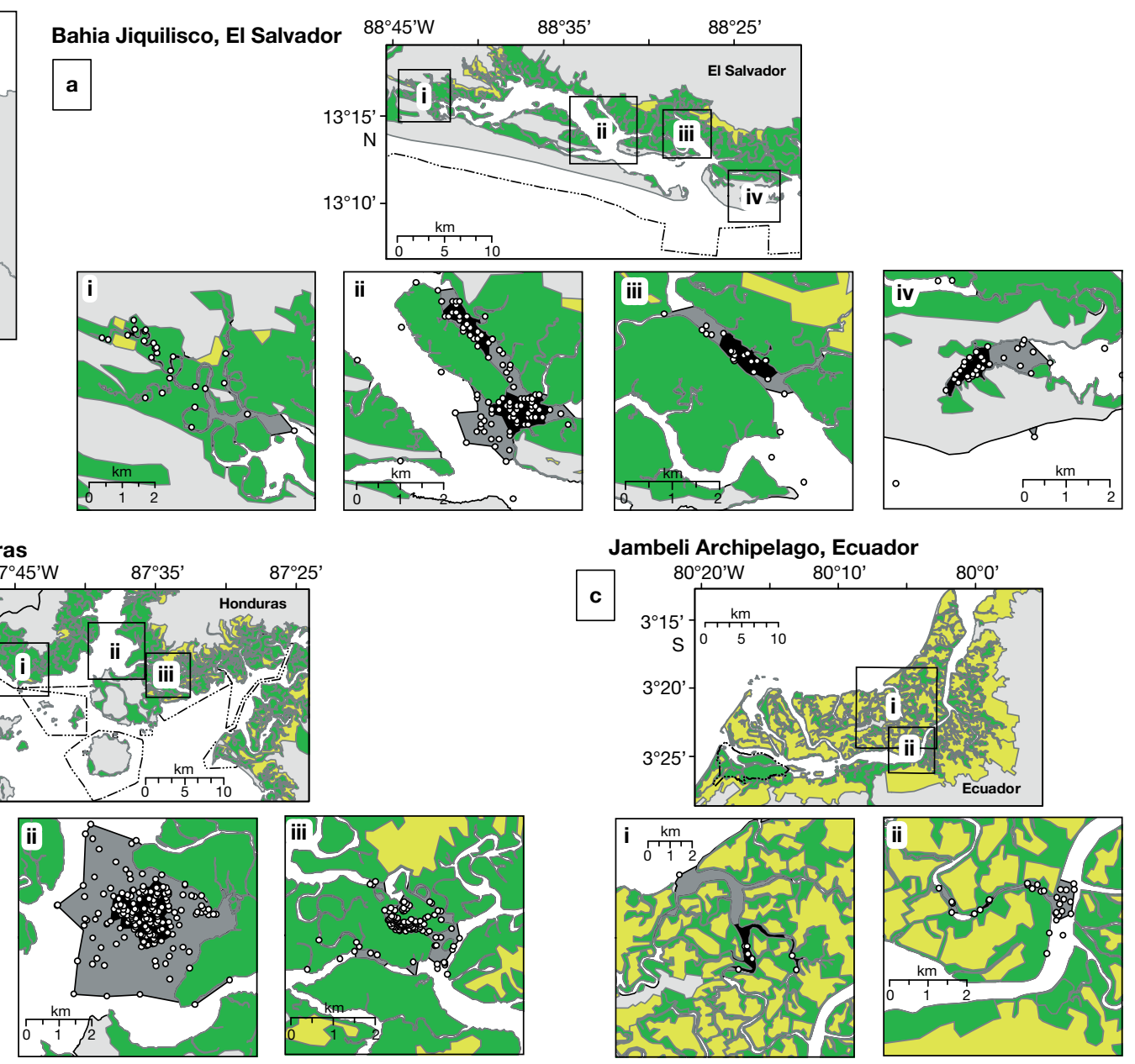

Fig. 4. Eretmochelys imbricata. Inshore (i.e. within estuaries) foraging home ranges for turtles at (a) Bahia Jiquilisco, El Salvador ( $\mathrm{n}=4$; i to iv), (b) Gulf of Fonseca, Honduras ( $\mathrm{n}=3$; i to iii) and (c) Jambeli Archipelago, Ecuador ( $\mathrm{n}=2$; i \& ii), with $90 \%$ (dark grey) and $50 \%$ (black) utilization distributions (UDs). Only location points and UDs over water are shown here. Mangrove saltwater forests (green), shrimp ponds (i.e. converted mangrove saltwater forests) (yellow) and marine protected areas (dashed lines) shown for reference 


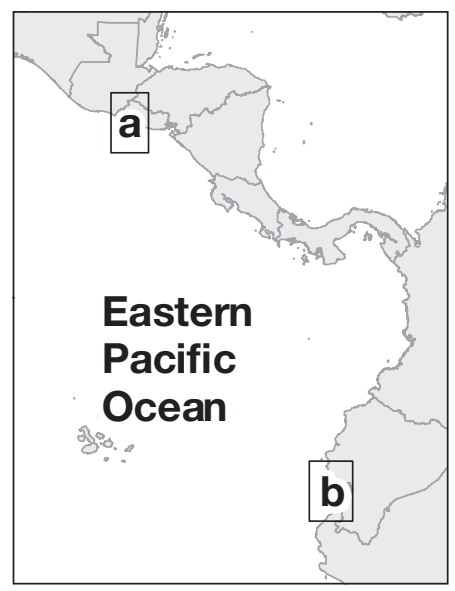

\section{Los Cobanos, El Salvador}
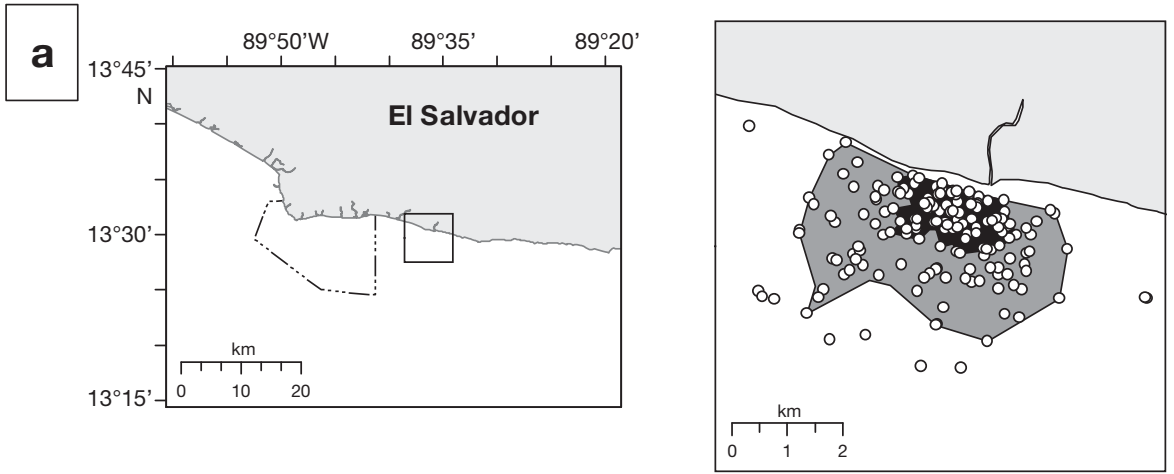

\section{Chanduy, Ecuador}
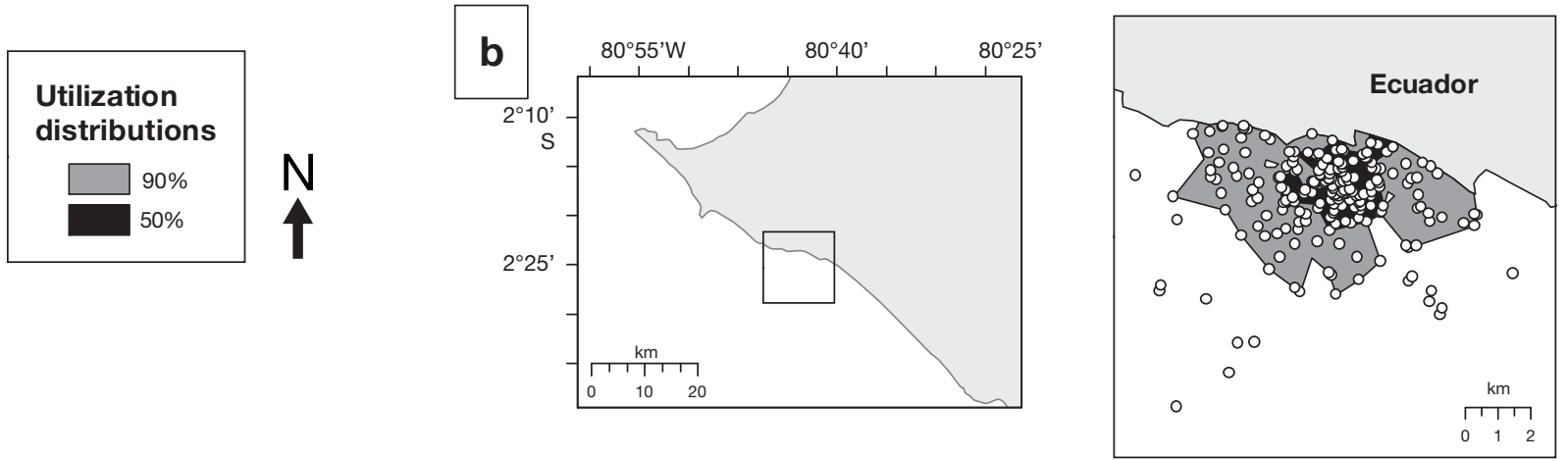

Fig. 5. Eretmochelys imbricata. Nearshore (i.e. open-coast) foraging home ranges for turtles at (a) Los Cóbanos, El Salvador $(\mathrm{n}=1)$ and (b) Chanduy, Ecuador ( $\mathrm{n}=1$ ), with $90 \%$ (dark grey) and $50 \%$ (black) utilization distributions (UDs). Only location points and UDs over water are shown here. Marine protected areas (dashed lines) shown for reference

$8.48 \mathrm{~km}^{2}$, and the mean $50 \%$ UD area was $1.47 \pm$ $1.69 \mathrm{~km}^{2}$. Both the 90 and $50 \%$ foraging home range areas for inshore turtles were substantially smaller, with a mean $90 \%$ UD of $4.23 \pm 5.12 \mathrm{~km}^{2}$ and a mean $50 \%$ UD of $0.92 \pm 0.89 \mathrm{~km}^{2}$ (Table 3). There were no correlations between turtle size or tracking duration and the area of foraging home ranges.

Table 3. Eretmochelys imbricata. Mean home range area $\left(\mathrm{km}^{2}\right)$ utilization distributions for inshore (i.e. within estuaries) and nearshore (i.e. along the open coast) hawksbills during the inter-nesting and foraging phases

\begin{tabular}{|lcc|}
\hline \multirow{2}{*}{ Area type } & \multicolumn{3}{c|}{$\begin{array}{c} \\
\end{array}$} & $90 \%$ & $50 \%$ \\
\hline Inter-nesting phase & & \\
Nearshore & 37.15 & 6.08 \\
Inshore & 13.46 & 2.03 \\
Foraging phase & & \\
Nearshore & 19.20 & 3.94 \\
Inshore & 4.23 & 0.92 \\
\hline
\end{tabular}

\section{Use of marine protected areas}

Of the 3166 combined location points for all turtles during all 3 movement phases, 2077 (65.6\%) fell within an existing MPA. By phase, a total of 431 (59.4\% of phase total), 93 (35.2\% of phase total) and 1553 ( $71.4 \%$ of phase total) location points fell within an existing MPA during the inter-nesting, migration and foraging phase, respectively (Table 4).

\section{DISCUSSION}

Our spatio-temporal characterizations of hawksbill Eretmochelys imbricata movements in the eastern Pacific have identified novel movement strategies and core habitats for the species. We found substantial consistency in movement patterns in turtles across the 6 capture locations, i.e. the majority of turtles exhibited fairly restricted migration distances, a strong adherence to the coast and the use of small home range areas. 
Table 4. Eretmochelys imbricata. Total location points, as well as number and percentage of points in marine protected areas (MPA) by country and per movement phase for all 15 turtles tracked in the present study. -: no turtles present in countries during movement phase

\begin{tabular}{|c|c|c|c|c|c|c|c|c|c|}
\hline \multirow{2}{*}{ Country } & \multicolumn{3}{|c|}{ Inter-nesting phase } & \multicolumn{3}{|c|}{ Migration phase } & \multicolumn{3}{|c|}{ _ Foraging phase } \\
\hline & Location points & In MPA & $\%$ & Location points & In MPA & $\%$ & Location points & In MPA & $\%$ \\
\hline El Salvador & 247 & 185 & 74.9 & 95 & 65 & 68.4 & 887 & 717 & 80.8 \\
\hline Nicaragua & 218 & 82 & 37.6 & 84 & 25 & 29.8 & - & - & - \\
\hline Honduras & - & - & - & - & - & - & 851 & 836 & 98.2 \\
\hline Ecuador & 261 & 164 & 62.8 & 85 & 3 & 3.5 & 438 & 0 & 0.0 \\
\hline Total & 726 & 431 & 59.4 & 264 & 93 & 35.2 & 2176 & 1553 & 71.4 \\
\hline
\end{tabular}

Though several hawksbills were tagged at distinct nesting sites, these individuals often migrated to common foraging grounds. Bahia Jiquilisco (El Salvador) and the Gulf of Fonseca (Honduras) were shared destinations for turtles from multiple tagging sites (Fig. 3), highlighting the significance of these areas for hawksbills throughout the region. Within each site, the spatial extent of foraging home ranges for all turtles was extremely limited. This was particularly true for individuals that established inshore foraging home ranges (Table 3 ). The average core area (i.e. $50 \%$ UD) used by these turtles was $<1 \mathrm{~km}^{2}$, a value that is orders of magnitude lower than those most recently reported for adult hawksbills in the Caribbean (Cuevas et al. 2008; but see Horrocks et al. 2001), and several orders of magnitude lower than those of several other adult sea turtle species (e.g. Shillinger et al. 2008, Hawkes et al. 2011). With Argos-based geographic positioning system (GPS) tracking technology becoming more widely available, it is likely there will soon be more accurate quantitative estimates of sea turtle area use, which may reveal increasingly restricted home range areas.

Turtles seek out high-productivity areas to maximize fitness (Shaver et al. 2005), and the use of such a limited area during the foraging phase may indicate an abundance of high-quality prey items at these foraging sites (Boyce \& McDonald 1999). Foraging hawksbills associate with mangrove saltwater forests in the eastern Pacific (Gaos et al. 2012), which are among the most resource-rich habitats along the eastern Pacific coastline (Dewalt et al. 1996). Nonetheless, the physical and biological composition (e.g. substrate, flora and fauna) of these sites has yet to be adequately characterized, and the principal diet items of hawksbills in these areas remain unknown. Local anecdotal reports indicate that mangrove shoots, benthic inverte- brates, shellfish, algae and sponges, the latter rumored to grow on the roots of mangroves and small submarine rock outcrops within estuaries, are all potentially important food items (L. Manzanares pers. comm.). Further research into hawksbill diet is of particular interest both from biological and conservation perspectives, particularly given the small average size of the adult female hawksbills in the present study (Horrocks et al. 2001, Troëng et al. 2005, Cuevas et al. 2008, Parker et al. 2009).

Hawksbills appear to move greater distances during their inter-nesting phase than during their foraging phase, which is reflected in the fact that the mean values for travel speed and distance between points were significantly greater $(p<0.05)$ in the former phase (Table 5). Turtles also generally used larger home range areas, moved further offshore and used longer stretches of coastline during the inter-nesting phase versus the foraging phase (Table 5). These results contrast with previous studies, which suggest that hawksbills in other ocean regions are relatively inactive during in the inter-nesting period (e.g. Hays et al. 1999, Houghton et al. 2008). We attribute the increased overall movement observed during this phase, at least in part, to the coastal shuttling between nesting sites and the high-use areas occupied between nesting events. The hawksbills tracked here concentrated movements during the inter-nesting phase at areas that were not directly adjacent to the

Table 5. Eretmochelys imbricata. Movement parameters for hawksbills during the 3 movement phases (inter-nesting, migration and foraging), including average distance travelled per day, average distance between points, average speed, average distance from the coast and total coastline used

\begin{tabular}{|lccccr|}
\hline $\begin{array}{l}\text { Movement } \\
\text { phase }\end{array}$ & $\begin{array}{c}\text { Distance } \\
\text { travelled per } \\
\text { day }(\mathrm{km})\end{array}$ & $\begin{array}{c}\text { Distance } \\
\text { between } \\
\text { points }(\mathrm{km})\end{array}$ & $\begin{array}{c}\text { Speed } \\
\left(\mathrm{km} \mathrm{h}^{-1}\right)\end{array}$ & $\begin{array}{r}\text { Distance } \\
\text { to coast } \\
(\mathrm{km})\end{array}$ & $\begin{array}{r}\text { Coastline } \\
\text { used } \\
(\mathrm{km})\end{array}$ \\
\hline Inter-nesting & 3.87 & 1.78 & 0.24 & 0.99 & 15.94 \\
Migration & 15.96 & 6.84 & 0.95 & 1.72 & 112.91 \\
Foraging & 2.54 & 1.18 & 0.14 & 0.31 & 9.36 \\
\hline
\end{tabular}


beaches where nests were deposited (average distance from nesting site $=7.03 \mathrm{~km}$; Figs. $1 \& 2$ ). However, whether hawksbills are inactive once reaching these areas, why they use these areas rather than those directly off the nesting beach, and what they do in these areas (e.g. feed, mate, socialize) remains unclear.

Two of our tagging sites, Bahia Jiquilisco (El Salvador) and Estero Padre Ramos (Nicaragua), are the primary hawksbill nesting rookeries in the eastern Pacific, together accounting for approximately $90 \%$ of the known nesting of the species in the region (Gaos et al. 2010, Altamirano et al. 2011, Liles et al. 2011). Conservation projects established at these 2 sites have documented nesting almost exclusively on shores within the estuaries (Altamirano et al. 2011, Liles et al. 2011). The fact that hawksbills in the eastern Pacific use mangrove habitats for both foraging and nesting may explain why the species went virtually undetected in the region for decades. Hawksbills in other parts of the world are primarily associated with coral reefs (Witzell 1983, Meylan 1988; but see Bjorndal \& Bolten 2010), which are typically located in areas with clear waters (Spalding et al. 2001). In the mangrove estuaries discussed here, visibility often does not extend beyond a few feet. Furthermore, hawksbills exhibit reduced surface time (Byles \& Swimmer 1994) and a tendency to maintain a larger portion of their carapace submerged during surfacing intervals when compared to other species (Bell \& Parmenter 2008). These factors make observing hawksbills in estuaries extremely difficult, and when coupled with low hawksbill abundance in the eastern Pacific (Gaos et al. 2010, Liles et al. 2011), likely explain the lack of early reports.

While hawksbills in the eastern Pacific have likely evolved the ability to exploit inshore mangrove estuary habitats due to a lack of coral reefs in the region (Gaos et al. 2012), the current disproportionate use of inshore mangrove estuaries by adults may be an indication that some of these areas represent lower risk habitat for the species. Being less conspicuous in mangrove estuaries, hawksbills may be less susceptible to overexploitation, and thus individuals inhabiting these areas may have gradually comprised a greater proportion of the population as turtles preferring open-coast habitats were impacted (i.e. geographic survivorship effect sensu van Dam et al. 2008).

The majority of sightings and research on juvenile hawksbills in the eastern Pacific have been reported in nearshore, open-coast habitats typical of the species in other regions of the world (e.g. Seminoff et al.
2003, Carrión 2010, Amorocho \& Tobón in press). Thus, an alternative explanation may be that the use of mangrove estuaries is a behavior more typical of adults. This is supported by recent and historical reports of hawksbills in nearshore habitats (e.g. Northwest and Central Pacific Mexico, Isla Gorgona in Colombia, Nicoya Peninsula in Costa Rica, Isla La Plata and Galapagos Islands in Ecuador) that almost exclusively report juveniles of the species (Seminoff et al. 2003, Carrión 2010, Gaos et al. 2010, Amorocho \& Tobón 2011).

Despite the predominant use of estuaries by the adult hawksbills tracked in the present study, 2 $(17.3 \%)$ individuals established foraging residencies in areas consisting of rock and/or coral reef substrata (Los Cobanos Reef in El Salvador and Chanduy in Ecuador). While research is needed to further characterize ontogenetic patterns of habitat use, our findings indicate that dichotomies in foraging area strategies do exist for adult hawksbills in the eastern Pacific, with some individuals using inshore mangrove estuaries and, to a lesser extent, others using open-coast rock and coral reefs.

We also found a within-rookery dichotomy in migratory strategies, with some turtles remaining near nesting sites and others migrating to disparate foraging grounds (Fig. 3). While hawksbill nonmigratory behavior has previously been documented for individuals inhabiting archipelagos (e.g. Mortimer \& Balazs 1999, Parker et al. 2009), our research provides the first clear evidence that adult female hawksbills occupying mainland coasts can also be non-migratory. While there are biological benefits to remaining in close proximity to nesting beaches after completing the nesting cycle, e.g. reduction in energy consumption (Shaver et al. 2005, Whiting et al. 2008), such behavior remains relatively rare in adult female sea turtles. While in the present study we report on movements of adult female hawksbills, we also tracked an adult male hawksbill that was captured while breeding adjacent to the primary nesting beach at the Estero Padre Ramos (Nicaragua) tagging site. This turtle never left the estuary during the 11 mo it was tracked, indicating that non-migratory behavior and the use of mangrove estuaries may also be characteristic of adult males of the species. Future studies will be vital to characterizing adult male hawksbill movements in the eastern Pacific.

When the hawksbills in the present study did migrate, the distances traveled were short and are dwarfed by the trans-oceanic migrations by other marine turtles in the same ocean basin (e.g. Seminoff et al. 2008, Shillinger et al. 2008). In nearly all cases, 
migration pathways were direct, as described by the MSI, suggesting that migrations were exclusively transit movements. The direct migrations may indicate that the areas traversed contain limited food resources as an effective behavioral strategy in such cases would be to swim directly to the highly productive foraging areas (Godley et al. 2002).

\section{Conservation implications}

Hawksbills in the eastern Pacific nest and forage in defined, spatially restricted areas. In contrast to the potential difficulties with developing conservation strategies for other sea turtle species that travel through and occupy vast areas in the eastern Pacific (e.g. Seminoff et al. 2008, Shillinger et al. 2008), hawksbill movement behavior in the region presents a unique and valuable conservation opportunity to focus protection efforts on high-use areas that support multiple life stages. Many of these high-use areas have already received conservation designation by the governing bodies. However, although $65.6 \%$ of the total location points for hawksbills fell within marine areas under some type of protective legislation (e.g. national park, wildlife refuge, or special management area), this statistic does not reflect the level of enforcement or active management these areas receive. Varying regulatory frameworks aside, many of these reserves are 'paper reserves' (Harris 2008), with essentially no enforcement mechanisms and where illegal activities (e.g. mangrove destruction, illegal fishing and turtle/egg poaching) remain commonplace (Dewalt et al. 1996, Blázquez \& Navarrete 1996, Gaos et al. 2010, Liles et al. 2011). Machalilla National Park has been an exception, with substantial investments by institutions and organizations leading to increased protection of hawksbills and their habitats within the park.

Despite the challenges, the fact that protective legislation is already in place at several areas of high hawksbill use provides an excellent opportunity for local stewardship and management. Efforts to strengthen management of protected areas and to initiate efforts to gain protective legislation for sites with no formal recognition (e.g. Jambeli Archipelago and Punta Amapala) will be vital to conservation and recovery of hawksbills in the eastern Pacific. Increased reserve management has accompanied the recent initiation of hawksbill conservation projects at Bahia Jiquilisco, Estero Padre Ramos and Machalilla, and protected areas are currently being proposed for the areas of Punta Amapala and the entire Gulf of
Fonseca. These initiatives bode well for the future of hawksbill turtles in the region.

From a stewardship perspective, promoting conservation of resident animals to local communities may be easier because the animals do not migrate to distant regions (Mortimer \& Balazs 1999). The governance structure may also be more uniform, which facilitates management, because the turtles are unlikely to cross jurisdictional and/or political boundaries where protection strategies or legislation may vary widely (Mortimer et al. 2007, Whiting et al. 2008).

Despite excellent conservation opportunities, dependence by hawksbills on a few geographically isolated sites (e.g. Bahia Jiquilisco, Gulf of Fonseca, Estero Padre Ramos and Jambeli Archipelago) also poses serious threats. Catastrophic climatic events (e.g. hurricanes, extreme flooding) or habitat degradation could severely jeopardize or potentially eliminate these critical nesting and foraging sites (Whiting et al. 2008). Commercial shrimp aquaculture has already taken a heavy toll on mangrove ecosystems in our study areas, particularly in the Jambeli Archipelago and eastern Gulf of Fonseca (Fig. 4), and represents a major and ongoing threat to hawksbills and mangrove habitats more broadly (Polidoro et al. 2010). Loss of mangroves has been linked to loss of ecosystem function and a decline in water quality within estuarine complexes (Chapman 1976, Duke 1992, Dewalt et al. 1996, Shervette et al. 2007), and hawksbills appeared to preferentially use areas of estuaries lined with relatively intact mangrove habitat over those converted to shrimp farms (Fig. 4). Additionally, the 2 densest hawksbill nesting and foraging sites (Bahia Jiquilisco and Estero Padre Ramos) are located in areas where estuary shorelines remain relatively undisturbed (Fig. 1).

The identification of specific areas where hawksbills aggregate also has the potential to increase poaching of adult hawksbills for tortoiseshell. Currently this practice remains virtually unheard of at our study sites, but considering the high value of tortoiseshell (Mortimer \& Donnelly 2008) that could quickly change with a few individuals intent on exploiting the market. While herein lies an inherent risk with publishing the maps in this document, we feel the benefits of focusing international attention on these sites outweigh the risks.

Lastly, several artisanal fisheries, primarily gillnets and blast fishing, are a major threat collectively to hawksbills in the eastern Pacific (Gaos et al. 2010, Liles et al. 2011, Vega \& Robles 2011). More than 30 individual hawksbills were killed by these activities 
in our study areas over the course of this research. Given that these fisheries operate exclusively in nearshore areas, the neritic home ranges and coastal migration paths of adult hawksbills increase the likelihood of potential bycatch interactions. Considering the small population size of hawksbills in this ocean region, these threats could easily lead to extirpation of the species in the eastern Pacific.

Acknowledgements. We thank Southwest Fisheries Science Center of the National Ocean and Atmospheric Administration, National Fish and Wildlife Foundation, US Fish and Wildlife Service, Machalilla National Park, Paso Pacifico, Asociación para el Desarrollo Empresarial y Ambiental de Puerto Parada, Fundación para la Protección del Arrecife de Los Cóbanos, Cooperativa de Pescadores El Maculís, Ministry of the Environment and Natural Resources of El Salvador, Cooperativa Multisectorial de Jiquilillo, Los Zorros y Padre Ramos and The Ocean Foundation for financial/ logisitical support. We also thank the following individuals: Rene Flores, Cristabel Flores, Georgina Mariona, Wilfredo Lopez, Tarla Peterson, Sarah Otterstrom, Liza Gonzalez, Salvador Sanchez, Perla Torres, Eduardo Altamirano Urbina, Eddy Maradiaga, Luís Manzanares, Micaela Peña, Juan Pablo Muñoz, Gabriela Anhalzer, Felipe Vallejo, Michelle Pico, Earl Possardt, Grover Jeane, Michael Carey, Philippe Gaspar, Remy Lopez, Michael Coyne and Harry Johnson. We acknowledge insightful comments from several anonymous reviewers.

\section{LITERATURE CITED}

Altamirano EJ, Torres P, Urteaga J, Gaos AR, Maradiaga E (2011) Tech Mem Proyecto de Conservación de Tortuga Carey (Eretmochelys imbricata) en la RN Estero Padre Ramos, Temporada 2010. Fauna and Flora International, Managua

Amorocho D, Tobón A (in press) Movements of hawksbill turtles Eretmochelys imbricata at Gorgona National Park and the Colombian Pacific using satellite tracking. In: Wallace BP, Jones TT (eds) Proceedings of the 31st annual symposium on sea turtle biology and conservation. NOAA Tech Mem NMFS-SEFSC

Argos (2008) Location and data collection satellite system user's guide. Argos, Toulouse

Beggs JA, Horrocks JA, Krueger BH (2007) Increase in hawksbill sea turtle Eretmochelys imbricata nesting in Barbados, West Indies. Endang Species Res 3:159-168

Bell IP, Parmenter CJ (2008) The diving behavior of internesting hawksbill turtles, Eretmochelys imbricata (Linnaeus 1766), on Milman Island reef, Queensland, Australia. Herpetol Conserv Biol 3:254-263

Beyer HL (2004) Hawth's analysis tools for ArcGIS. Available at www.spatialecology.com/htools

Bjorndal KA, Bolten AB (2010) Hawksbill sea turtles in seagrass pastures: success in a peripheral habitat. Mar Biol 157:135-145

Blázquez LA, Navarrete G (1996) Identificación de un proyecto Araucaria XXI en el Golfo de Fonseca. Tech Mem Agencia Española de Cooperación Internacional para el Desarollo (AECID), Madrid, and Comisión Centroamericana de Ambiente y Desarrollo (CCAD), Antiguo Cuscatlán, El Salvador
Block BA (2005) Physiological ecology in the 21st century: advancements in biologging science. Integr Comp Biol 45:305-320

Blumenthal JM, Solomon J, Bell CD, Austin TJ and others (2006) Satellite tracking highlights the need for international cooperation in marine turtle management. Endang Species Res 2:51-61

Boyce MS, McDonald LL (1999) Relating populations to habitats using resource selection functions. Trends Ecol Evol 14:268-272

Byles RA, Swimmer YB (1994) Post-nesting migration of Eretmochelys imbricata in the Yucatan Peninsula. In: Bjorndal KA, Bolten AB, Johnson DA, Eliazar PJ (eds) Proceedings of the 14 th annual symposium on sea turtle biology and conservation. NOAA Tech Mem NMFSSEFSC, Hilton Head, SC, p 202

Carrión J (2010) Área de actividad local, dieta e intensidad de uso del habitat de forrajeo de la tortuga carey (Eretmochelys imbricata) en el Pacífico norte de Costa Rica. Master's dissertation, Universidad Autónoma de Baja California Sur, La Paz

Chapman VJ (1976) Mangrove vegetation. J. Cramer, Vaduz > Coyne MC, Godley BJ (2005) Satellite Tracking and Analysis Tool (STAT): an integrated system for archiving, analyzing and mapping animal tracking data. Mar Ecol Prog Ser 301:1-7

Creel S, Creel NM (2002) The African wild dog. Behavior, ecology and conservation. Monographs in behavior and ecology, Princeton University Press, Princeton, NJ

> Crouse DT, Crowder LB, Caswell H (1987) A stage-based population model for loggerhead sea turtles and implications for conservation. Ecology 68:1412-1423

> Crowder LB, Crouse DT, Heppell SS, Martin TH (1994) Predicting the impact of turtle excluder devices on loggerhead sea turtle populations. Ecol Appl 4:437-445

Cuevas E, Abreu-Grobois FA, Guzman-Hernandez V, Liceaga-Correa MA, van Dam RP (2008) Post-nesting migratory movements of hawksbill turtles Eretmochelys imbricata in waters adjacent to the Yucatan Peninsula, Mexico. Endang Species Res 10:123-133

> Dewalt BR, Vergne P, Hardin M (1996) Shrimp aquaculture development and the environment: people, mangroves and fisheries on the Gulf of Fonseca, Honduras. World Dev 24:1193-1208

Duke NC (1992) Mangrove floristics and biogeography. In: Robertson AI, Alongi D (eds) Tropical mangrove ecosystems. American Geophysical Union, Washington, DC, p 63-100

Gaos AR, Abreu A, Alfaro JA, Amorocho D and others (2010) Signs of hope in the eastern Pacific: international collaboration reveals encouraging status for a severely depleted population of hawksbill turtles Eretmochelys imbricata. Oryx 44:595-601

Gaos AR, Lewison RL, Yañez IL, Wallace BP and others (2012) Shifting the life-history paradigm: discovery of novel habitat use by hawksbill turtles. Biol Lett 8:54-56

Getz W, Wilmers C (2004) A local nearest-neighbor convexhull construction of home ranges and utilization distributions. Ecography 27:489-505

Getz WM, Fortmann-Roe S, Cross PC, Lyons AJ, Ryan SJ, Wilmers CC (2007) LoCoH: nonparameteric kernel methods for constructing home ranges and utilization distributions. PLoS One 2:e207

Godley BJ, Richardson S, Broderick AC, Coyne MS, Glen F, Hays GC (2002) Long-term satellite telemetry of the 
movements and habitat utilisation by green turtles in the Mediterranean. Ecography 25:352-362

- Godley BJ, Lima EHSM, Åkesson S, Broderick AC and others (2003) Movement patterns of green turtles in Brazilian coastal waters described by satellite tracking and flipper tagging. Mar Ecol Prog Ser 253:279-288

Godley J, Blumenthal JM, Broderick AC, Coyne MS, God-

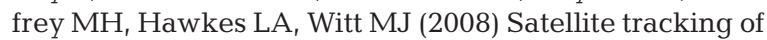
sea turtles: Where have we been and where do we go next? Endang Species Res 4:3-22

Harris RB (2008) Wildlife conservation in China: preserving the habitat of China's wild west. M. E. Sharpe, Armonk, NY

> Hawkes LA, Witt MJ, Broderick AC, Coker JW and others (2011) Home on the range: spatial ecology of loggerhead turtles in Atlantic waters of the USA. Divers Distrib 17: 624-640

- Hays GC, Luschi P, Papi F, del Seppia C, Marsh R (1999) Changes in behaviour during the inter-nesting period and post-nesting migration for Ascension Island green turtles. Mar Ecol Prog Ser 189:263-273

- Hays GC, Arkesson S, Godley BJ, Luschi P, Santidrian P (2001) The implications of location accuracy for the interpretation of satellite-tracking data. Anim Behav 61: 1035-1040

> Heppell SS (1998) Application of life-history theory and population model analysis to turtle conservation. Copeia 1998:367-375

Heppell SS, Crouse DT, Crowder LB (1996) A model evaluation of headstarting as a management tool for long-lived turtles. Ecol Appl 6:556-565

Horrocks JA, Vermeer LA, Krueger B, Coyne M, Schroeder BA, Balazs GH (2001) Migration routes and destination characteristics of post-nesting hawksbill turtles satellitetracked from Barbados, West Indies. Chelonian Conserv Biol 4:107-114

> Houghton JDR, Cedras A, Myers AE, Liebsch N, Metcalfe JD, Mortimer JA, Hays GC (2008) Measuring the state of consciousness in a free-living diving sea turtle. J Exp Mar Biol Ecol 356:115-120

> Knight CM, Kenward RE, Gozlan RE, Hodder KH, Walls SS, Lucas MC (2009) Home-range estimation within complex restricted environments: importance of method selection in detecting seasonal change. Wildl Res 36: 213-224

> Liles MJ, Jandres MV, López WA, Mariona GI, Hasbún CR, Seminoff JA (2011) Hawksbill turtles (Eretmochelys imbricata) in El Salvador: nesting distribution and mortality at the largest remaining nesting aggregation in the eastern Pacific Ocean. Endang Species Res 14:23-30

Lopez R, Malardé JP (2011) Improving ARGOS Doppler location using Kalman filtering. Collecte Localisation Satellites, Ramonville Saint-Agne

Loveridge AJ, Valeix M, Davidson Z, Murindagomo F, Hervé F, Macdonald DW (2009) Changes in home range size of African lions in relation to pride size and prey biomass in a semi-arid savanna. Ecography 32:953-962

> Luschi P, Hays GC, del Seppia C, Marsh R, Papi F (1998) The navigational feats of green sea turtles migrating from Ascension Island investigated by satellite telemetry. Proc Biol Sci 265:2279-2284

Maxwell SM, Breed GA, Nickel BA, Makanga-Bahouna J and others (2011) Using satellite tracking to optimize protection of long-lived marine species: olive ridley sea turtle conservation in central Africa. PLoS One 6:e19905
Meylan A (1988) Spongivory in hawksbill turtles: a diet of glass. Science 239:393-395

Meylan AB (1999) Status of the hawksbill turtle (Eretmochelys imbricata) in the Caribbean region. Chelonian Conserv Biol 3:177-184

Mitchell SV (1998) Use of epoxy in telemeter attachment. In: Abreu-Grobois FA, Briseño-Dueñas R, Marquez R, Sarti $\mathrm{L}$ (eds) Proceedings of the 18th annual international symposium on sea turtle biology and conservation. NMFSSEFSC-NOAA, Washington, DC, p 254-255

Mortimer JA, Balazs GH (1999) Post-nesting migrations of hawksbill turtles in the granitic Seychelles and implications for conservation. In: Kalb HJ, Wibbels T (eds) Proceedings of the 19th annual symposium on sea turtle biology and conservation. NMFS-SEESC-NOAA, Washington, DC, p 22-26

Mortimer JA, Donnelly M (2008) Eretmochelys imbricata. In: IUCN red list of threatened species, V. 2010.1. IUCN, Gland. Available at: www.iucnredlist.org (accessed 15 July 2011)

Mortimer JA, Meylan PA, Donnelly M (2007) Whose turtles are they, anyway? Mol Ecol 16:17-18

Nichols WJ, Resendiz A, Seminoff JA, Resendiz B (2000) Transpacific migration of a loggerhead turtle monitored by satellite telemetry. Bull Mar Sci 67:937-947

Parker DM, Balazs GH, King CS, Katahira L, Gilmartin W (2009) Short range movements of hawksbill turtles (Eretmochely imbrica) from nesting to foraging areas within the Hawaiian Islands. Pac Sci 3:371-382

Plotkin P (2003) Adult migrations and habitat use. In: Lutz PL, Musick JA, Wyneken J (eds) The biology of sea turtles, Vol 2. CRC Press, Boca Raton, FL, p 225-241

Polidoro BA, Carpenter KE, Collins L, Duke NC and others (2010) The loss of species: mangrove extinction risk and geographic areas of global concern. PLoS One 5:e10095

Powell RA (2000) Animal home ranges and territories and home range estimators. In: Boitani L, Fuller TK (eds) Research techniques in animal ecology - controversies and consequences. Columbia University Press, New York, NY, p 65-110

Royer F, Lutcavage M (2008) Filtering and interpreting location errors in satellite telemetry of marine animals. J Exp Mar Biol Ecol 359:1-10

Schmid JR, Bolten AB, Bjorndal KA, Lindberg WJ (2002) Activity patterns of Kemp's ridley turtles (Lepidochelys kempii) in the coastal waters of the Cedar Keys, Florida. Mar Biol 140:215-228

- Schofield G, Bishop CM, MacLean G, Brown P and others (2007) Novel GPS tracking of sea turtles as a tool for conservation management. J Exp Mar Biol Ecol 347:58-68

Seminoff JA, Resendiz A, Nichols WJ (2002) Home range of green turtles Chelonia mydas at a coastal foraging area in the Gulf of California, Mexico. Mar Ecol Prog Ser 242: 253-265

- Seminoff JA, Nichols WJ, Resendiz A, Brooks L (2003) Occurrence of hawksbill turtles, Eretmochelys imbricata, near Baja California. Pac Sci 57:9-16

Seminoff JA, Zárate P, Coyne M, Foley DG, Parker D, Lyon BN, Dutton PH (2008) Post-nesting migrations of Galápagos green turtles Chelonia mydas in relation to oceanographic conditions: integrating satellite telemetry with remotely sensed ocean data. Endang Species Res 4: $57-72$

Shaver DJ, Schroeder BA, Byles RA, Buchfield PM, Pena J, Marquez R, Martinez HJ (2005) Movements and home 
ranges of adult male Kemp's ridley sea turtles (Lepidochelys kempii) in the Gulf of Mexico investigated by satellite telemetry. Chelonian Conserv Biol 4:817-827

Shervette VR, Aguirre WE, Blacio E, Cevallos R, Gonzalez M, Pozo F, Gelwick F (2007) Fish communities of a disturbed mangrove wetland and an adjacent tidal river in Palmar, Ecuador. Estuar Coast Shelf Sci 72:115-128

Shillinger GL, Palacios DM, Bailey H, Bograd SJ and others (2008) Persistent leatherback turtle migrations present opportunities for conservation. PLoS Biol 6:e171

Spalding MD, Ravilious C, Green EP (2001) World atlas of coral reefs. University of California Press, Berkeley, CA

Swihart RK, Slade NA (1985) Influence of sampling interval on estimates of home-range size. J Wildl Manag 49: 1019-1025

Troëng S, Dutton PH, Evans D (2005) Migration of hawksbill turtles Eretmochelys imbricata from Tortuguero, Costa Rica. Ecography 28:394-402

Urian KW, Hofmann S, Wells RS (2009) Fine-scale population structure of bottlenose dolphins (Tursiops truncatus) in Tampa Bay, Florida. Mar Mamm Sci 25:619-638

van Dam RP, Diez CE, Balazs GH, Colón LA, Colón W, McMillan W, Shroeder B (2008) Sex-specific migration

Editorial responsibility: Rory Wilson,

Swansea, UK patterns of hawksbill turtles breeding at Mona Island, Puerto Rico. Endang Species Res 4:85-94

Vega AJ, Robles Y (2011) Evaluación Del Impacto de la Pesca Artesanal Sobre Tortugas Marinas en el Golfo de Chiriquí. In: Book of abstracts, 5th regional symposium on marine turtles in the southeastern Pacific. Smithsonian Tropical Research Institute, p 17

Wallace BP, DiMatteo AD, Hurley BJ, Finkbeiner EM and others (2011) Regional Management Units for marine turtles: a novel framework for prioritizing conservation and research across multiple scales. PLoS One 5:e15465

Whiting SD, Murray W, Macrae I, Thorn R, Chongkin M, Koch AU (2008) Non-migratory breeding by isolated green sea turtles (Chelonia mydas) in the Indian Ocean: biological and conservation implications. Naturwissenschaften 95:355-360

Witt MJ, Bonguno EA, Broderick AC, Coyne MS and others (2011) Tracking leatherback turtles from the world's largest rookery: assessing threats across the South Atlantic. Proc R Soc Lond B 278:2338-2347

Witzell W (1983) Synopsis of biological data on the hawksbill turtle, Eretmochelys imbricata (Linnaeus, 1766). FAO Fish Synop 137, FAO, Rome

Submitted: October 10, 2011; Accepted: January 10, 2012 Proofs received from author(s): March 23, 2012 